\title{
PERILAKU MUNAFIK INDIKATOR GANGGUAN JIWA
}

\author{
AGUST HANDINI \\ Penulis adalah Dosen IAIN Pontianak
}

\begin{abstract}
ABSTRAK
Orang-orang munafik pada dasarnya adalah mereka yang ingkar kepada Allah, dan RasulNya, kendatipun secara lahir mereka memakai baju mukmin. Abu Bakar Jabir Al-Jaziri berpendapat bahwa orang-orang munafik itu adalah mereka yang menampakkan keimanan terhadap orang-orang mukmin dengan ucapan-ucapan mereka, akan tetapi menyembunyikan kekafiran dalam hati mereka dan juga mengingkari syara' serta kufur untuk kepentingan mereka kepada Allah dan Rasul-Nya.

Dalam pandangan Murtadha Muthahari, kemunafikkan dimaknai sebagai sikap bermuka dua dan menampakkan diri secara berbeda dari keadaan yang seseungguhnya. Kendati merupakan sifat yang licik, kemunafikkan menunjukkan evolusi manusia. Artinya manakala manusia jauh lebuh berkembang daripada binatang biasanya tidak memiliki sifat seperti itu.

Tanda orang munafik ada tiga :

- Apabila ia berbicara berdusta,

- Apabila ia berjani ia ingkar, dan

Apabila dia dipercayai ia berkhianat. Ciri yang paling mendasar adalah kebimbangannya antara keimanan dan kekafiran serta ketakmampuannya membuat sikap yang tegas dan jelas berkaitan dengan keyakinan tauhid. Hal itu karena ia adalah pribadi yang kurang percaya diri. Mereka tidak dapat membuat keputusan yang tegas dan jelas untuk bergabung dengan kaum mukminin atau dengan kaum musyrikin.
\end{abstract}

\section{PENDAHULUAN}

Dalam Al-Quran kita temukan klasifikasi manusia, berdasarkan aqidahnya dalam tiga golongan yaitu : orang-orang yang beriman, orang-orang yang kafir, dan orang-orang yang munafik. Masing-masing pola dari ketiga pola ini mempunyai sifat utama umum yang membedakan dari dua pola yang lainnya. Klasifikasi manusia berdasarkan aqidah dan petunjuk. Ketiga pola manusia tersebut, dikemukakan AlQuran di berbagai tempat. Misalnya saja dalam permulaan surat Al-Baqarah dimana orang-orang beriman disebut dalam 4 ayat (2-5), orang-orang kafir disebut dalam 2 ayat (6-7), dan orang-orang munafik dalam 13 ayat $(8-20)$.

Tipe munafik, yaitu mereka yang beriman kepada Allah SWT, dan hari akhir, tetapi imannya hanya dimulut belaka, sementara hatinya ingkar. Mereka ingin menipu Allah dan orang mukmin, walaupun sebenarnya ia menipu dirinya sendiri, sedang mereka tidak sadar. Hati mereka berpenyakit, dan semakin parah penyakitnya karena membuat kerusakan, menambah kebodohan, bersekutu dengan setan untuk mengolok-olok orang-orang mukmin. Mereka tidak mendapat penerangan dan petunjuk, sehingga 
senantiasa dalam kegelapan. (Abdul Mujib 2006 : 174).

Munafik adalah golongan yang berkepribadian sangat lemah dan bimbang. Mereka tidak dapat membuat suatu sikap yang jelas berkenaan dengan keimanan. AlQuran telah menyebutkan ciri-ciri khas mereka dan mengancam mereka dengan azab yang teramat berat. (M. Ustman Najati $2005: 389$ ).

Orang munafik adalah seorang oportunis. Jika kaum muslimin memperoleh keberuntungan, orang munafik mengatakan bahwa ia bersama mereka agar memperoleh keberuntungan itu. Jika orang-orang musyrik yang mendapat keberuntungan, pun mengatakan bahwa ia bersama mereka agar memeperoleh keberuntungan itu.

Orang munafik juga seorang pengecut. Apabila diajak untuk ikut serta dalam peperangan, ia pun diliputi ketakutan dan menyodorkan banyak alasan agar tidak ikut berperang. Ia akan selalau berupaya memperdaya orang lain. Untuk itu, ia berusaha mempengaruhi orang lain dengan kata-kata yang manis dan penampilan yang menawan. Oleh karena itu, ia akan berupaya membela diri dan mencari-cari pembenaran atas semua tindakannya.

\section{AYAT-AYAT YANG BERKAITAN}

QS. Ali Imran (3) : 165 - 168

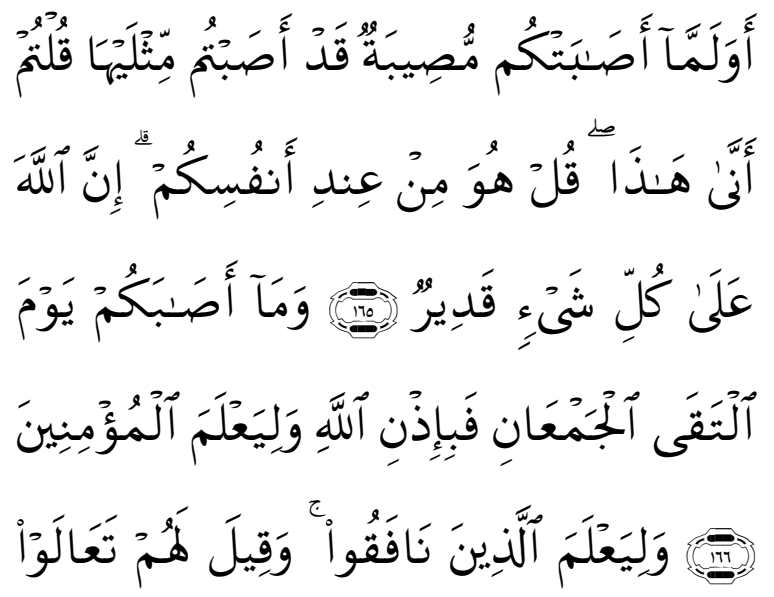

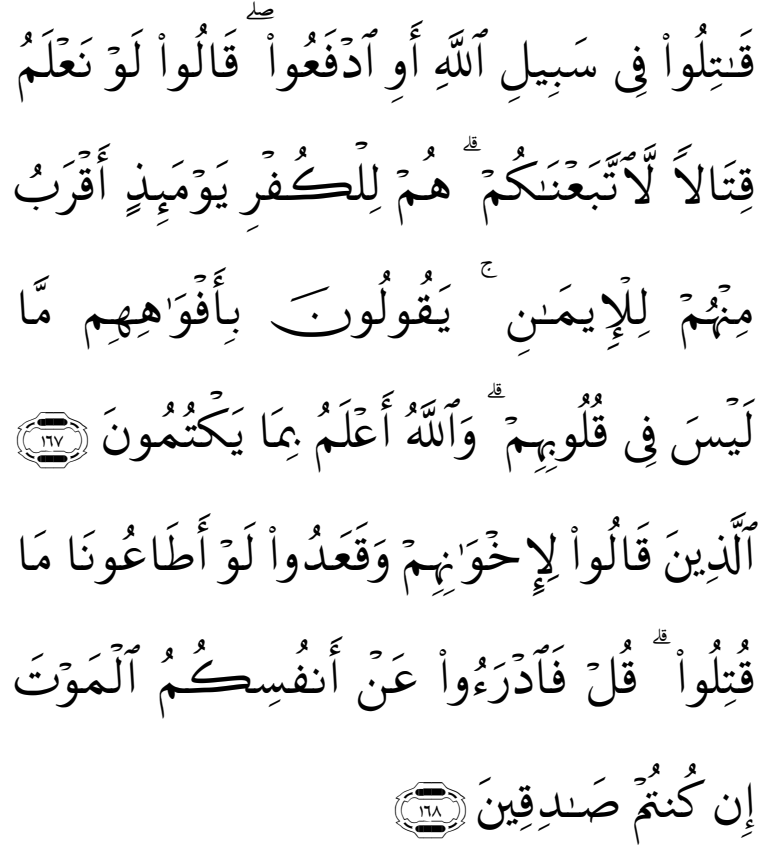

165. Dan Mengapa ketika kamu ditimpa musibah (pada peperangan Uhud), padahal kamu Telah menimpakan kekalahan dua kali lipat kepada musuh-musuhmu (pada peperangan Badar), kamu berkata: "Darimana datangnya (kekalahan) ini?" Katakanlah: "Itu dari (kesalahan) dirimu sendiri". Sesungguhnya Allah Maha Kuasa atas segala sesuatu.

166. Dan apa yang menimpa kamu pada hari bertemunya dua pasukan, Maka (kekalahan) itu adalah dengan izin (takdir) Allah, dan agar Allah mengetahui siapa orang-orang yang beriman.

167. Dan supaya Allah mengetahui siapa orang-orang yang munafik. kepada mereka dikatakan: "Marilah berperang di jalan Allah atau pertahankanlah (dirimu)". mereka berkata: "Sekiranya kami mengetahui akan terjadi peperangan, tentulah kami mengikuti kamu"[247]. mereka pada hari itu lebih dekat kepada kekafiran dari pada keimanan. mereka mengatakan dengan mulutnya apa yang tidak terkandung dalam hatinya. dan Allah lebih mengetahui 
dalam hatinya. dan Allah lebih mengetahui apa yang mereka sembunyikan.

168. Orang-orang yang mengatakan kepada saudara-saudaranya dan mereka tidak turut pergi berperang: "Sekiranya mereka mengikuti kita, tentulah mereka tidak terbunuh". Katakanlah: "Tolaklah kematian itu dari dirimu, jika kamu orang-orang yang benar".Ucapan Ini ditujukan kepada nabi dan sahabat-sahabat beliau sebagai ejekan, Karena mereka memandang nabi tidak tahu taktik berperang, sebab beliau melakukan peperangan ketika jumlah kaum muslimin sedikit. Ucapan Ini dapat digunakan untuk mengelakkan cercaan yang ditujukan kepada diri orang-orang munafik sendiri.

QS. Al Munaafiqun (63) : 1-8

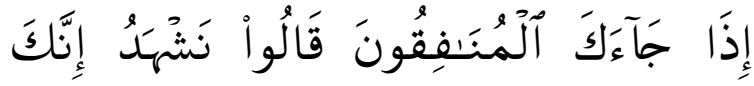

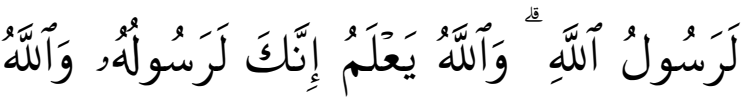

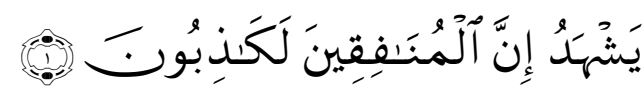

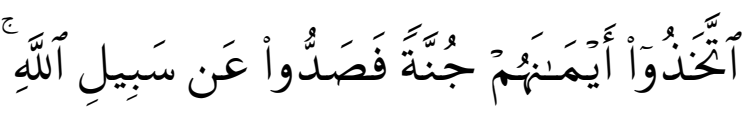

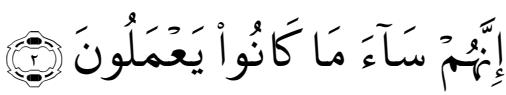

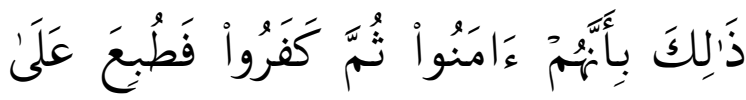

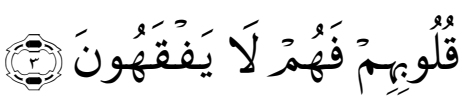

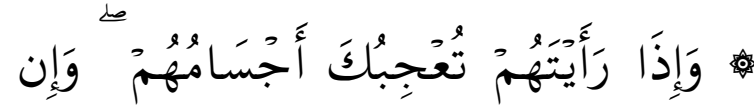

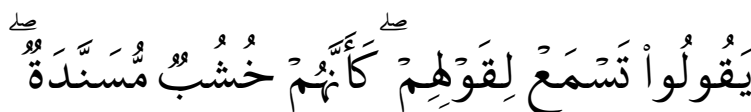

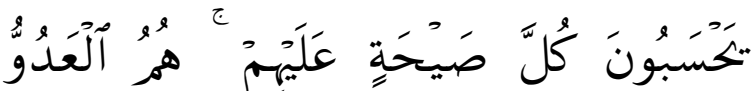

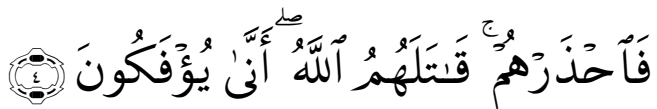

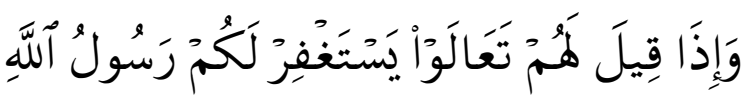

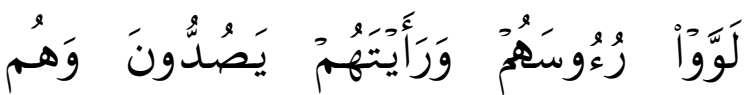
مُسْتَكَكِرْونَ

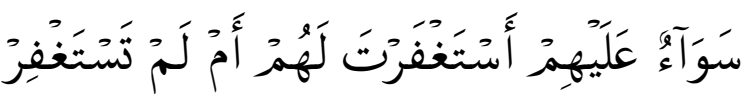

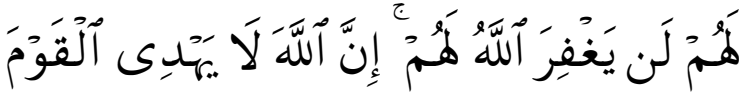

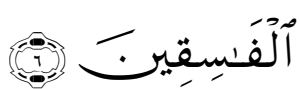

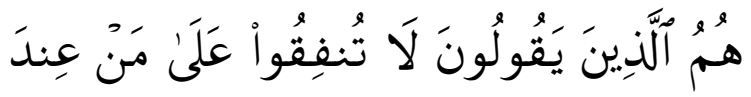

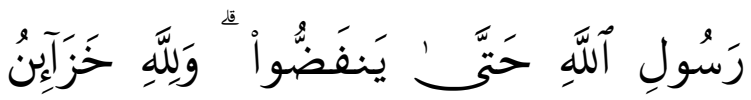

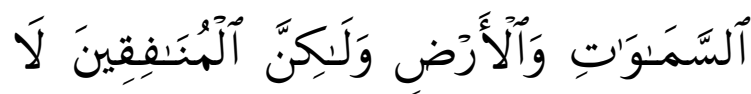
يَفْقَهُونَ

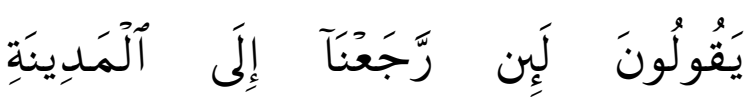

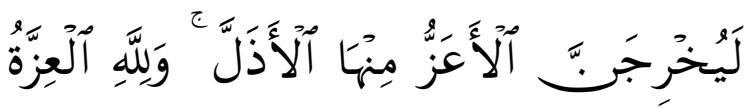
وَلَكِكن.

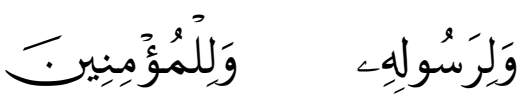

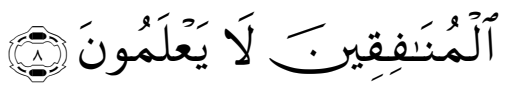

1. Apabila orang-orang munafik datang kepadamu, mereka berkata: "Kami mengakui, bahwa Sesungguhnya kamu benar-benar Rasul Allah". dan Allah mengetahui bahwa Sesungguhnya kamu benar-benar Rasul-Nya; dan Allah mengetahui bahwa Sesungguhnya 
orang-orang munafik itu benar-benar orang pendusta.

2. Mereka itu menjadikan sumpah mereka sebagai perisai, lalu mereka menghalangi (manusia) dari jalan Allah. Sesungguhnya amat buruklah apa yang Telah mereka kerjakan.

3. Yang demikian itu adalah Karena bahwa Sesungguhnya mereka Telah beriman, Kemudian menjadi kafir (lagi) lalu hati mereka dikunci mati; Karena itu mereka tidak dapat mengerti.

4. Dan apabila kamu melihat mereka, tubuh-tubuh mereka menjadikan kamu kagum. dan jika mereka Berkata kamu mendengarkan perkataan mereka. mereka adalah seakan-akan kayu yang tersandar. mereka mengira bahwa tiaptiap teriakan yang keras ditujukan kepada mereka. mereka Itulah musuh (yang sebenarnya) Maka waspadalah terhadap mereka; semoga Allah membinasakan mereka. bagaimanakah mereka sampai dipalingkan (dari kebenaran)?

5. Dan apabila dikatakan kepada mereka: marilah (beriman), agar Rasulullah memintakan ampunan bagimu, mereka membuang muka mereka dan kamu lihat mereka berpaling sedang mereka menyombongkan diri.

6. Sama saja bagi mereka, kamu mintakan ampunan atau tidak kamu mintakan ampunan bagi mereka. Sesungguhnya Allah tidak memberi petunjuk kepada orang-orang yang fasik.

7. Mereka orang-orang yang mengatakan (kepada orang-orang Anshar): "Janganlah kamu memberikan perbelanjaan kepada orang-orang (Muhajirin) yang ada disisi Rasulullah supaya mereka bubar (meninggalkan Rasulullah)." padahal kepunyaan Allahlah perbendaharaan langit dan bumi, tetapi orang-orang munafik itu tidak memahami.

8. Mereka berkata: "Sesungguhnya jika kita Telah kembali ke Madinah, benar- benar orang yang Kuat akan mengusir orang-orang yang lemah dari padanya." padahal kekuatan itu hanyalah bagi Allah, bagi rasul-Nya dan bagi orangorang mukmin, tetapi orang-orang munafik itu tiada Mengetahui. mereka bersumpah bahwa mereka beriman adalah untuk menjaga harta mereka supaya jangan dibunuh atau ditawan atau dirampas hartanya.mereka diumpamakan seperti kayu yang tersandar, maksudnya untuk menyatakan sifat mereka yang buruk meskipun tubuh mereka bagus-bagus dan mereka pandai berbicara, akan tetapi Sebenarnya otak mereka adalah kosong tak dapat memahami kebenaran. Maksudnya: kembali dari peperangan Bani Musthalik.

\section{QS. An Nissa (4) : 88-91}
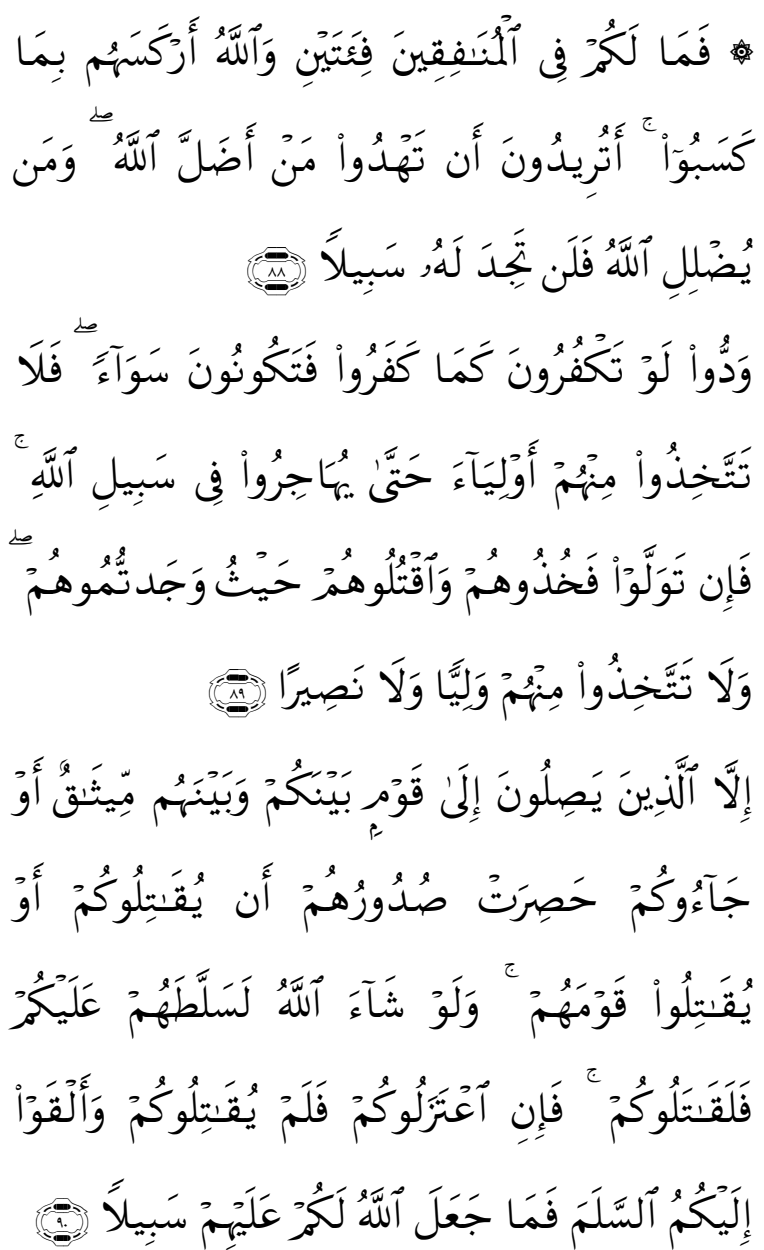
سَتَجِدُونَ ءَاخَرِينَ يُريدُونَ أَنْ يَأُمَنُوكُمْ وَيَأْمَنُواْ

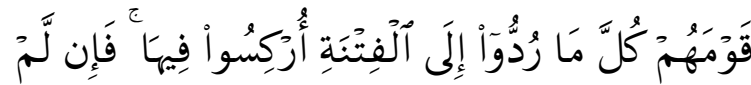

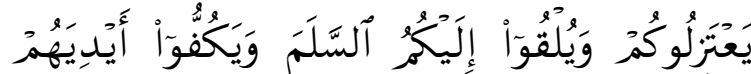

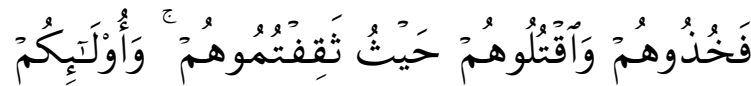

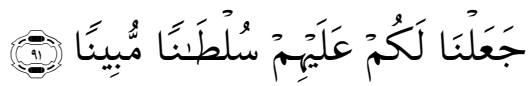

88. Maka Mengapa kamu (terpecah) menjadi dua golongan dalam (menghadapi) orang-orang munafik, padahal Allah Telah membalikkan mereka kepada kekafiran, disebabkan usaha mereka sendiri ? apakah kamu bermaksud memberi petunjuk kepada orang-orang yang Telah disesatkan Allah? barangsiapa yang disesatkan Allah, sekali-kali kamu tidak mendapatkan jalan (untuk memberi petunjuk) kepadanya.

89. Mereka ingin supaya kamu menjadi kafir sebagaimana mereka Telah menjadi kafir, lalu kamu menjadi sama (dengan mereka). Maka janganlah kamu jadikan di antara mereka penolong-penolong(mu), hingga mereka berhijrah pada jalan Allah. Maka jika mereka berpaling, tawan dan Bunuhlah mereka di mana saja kamu menemuinya, dan janganlah kamu ambil seorangpun di antara mereka menjadi pelindung, dan jangan (pula) menjadi penolong,

90. Kecuali orang-orang yang meminta perlindungan kepada sesuatu kaum, yang antara kamu dan kaum itu Telah ada perjanjian (damai), atau orangorang yang datang kepada kamu sedang hati mereka merasa keberatan untuk memerangi kamu dan memerangi kaumnya. kalau Allah menghendaki, tentu dia memberi kekuasaan kepada mereka terhadap kamu, lalu Pastilah mereka memerangimu. tetapi jika mereka membiarkan kamu, dan tidak memerangi kamu serta mengemukakan perdamaian kepadamu Maka Allah tidak memberi jalan bagimu (untuk menawan dan membunuh) mereka.

91. Kelak kamu akan dapati (golongangolongan) yang lain, yang bermaksud supaya mereka aman dari pada kamu dan aman (pula) dari kaumnya. setiap mereka diajak kembali kepada fitnah (syirik), merekapun terjun kedalamnya. Karena itu jika mereka tidak membiarkan kamu dan (tidak) mau mengemukakan perdamaian kepadamu, serta (tidak) menahan tangan mereka (dari memerangimu), Maka tawanlah mereka dan Bunuhlah mereka dan merekalah orang-orang yang kami berikan kepadamu alasan yang nyata (untuk menawan dan membunuh) mereka.

Maksudnya: golongan orang-orang mukmin yang membela orang-orang munafik dan golongan orang-orang mukmin yang memusuhi mereka. disesatkan Allah berarti: bahwa orang itu sesat berhubung keingkarannya dan tidak mau memahami petunjukpetunjuk Allah. dalam ayat ini, Karena mereka itu ingkar dan tidak mau memahami apa sebabnya Allah menjadikan nyamuk sebagai perumpamaan, Maka mereka itu menjadi sesat. diriwayatkan bahwa beberapa orang Arab datang kepada Rasulullah s.a.w. di Madinah. lalu mereka masuk islam, Kemudian mereka ditimpa demam Madinah, Karena itu mereka kembali kafir lalu mereka keluar dari Madinah. Kemudian mereka berjumpa dengan sahabat nabi, lalu sahabat menanyakan sebab-sebab mereka meninggalkan Madinah. mereka menerangkan bahwa mereka ditimpa demam Madinah. sahabat-sahabat berkata: Mengapa kamu tidak mengambil teladan yang baik dari Rasulullah? sahabat-sahabat terbagi kepada dua golongan dalam hal 
ini. yang sebahagian berpendapat bahwa mereka Telah menjadi munafik, sedang yang sebahagian lagi berpendapat bahwa mereka masih Islam. lalu turunlah ayat Ini yang mencela kaum muslimin Karena menjadi dua golongan itu, dan memerintahkan supaya orang-orang Arab itu ditawan dan dibunuh, jika mereka tidak berhijrah ke Madinah, Karena mereka disamakan dengan kaum musyrikin yang lain, ayat Ini menjadi dasar hukum suaka, tidak memihak dan Telah mengadakan hubungan dengan kaum muslimin Maksudnya: menyerah.

QS. At Taubah (9) : 67-70
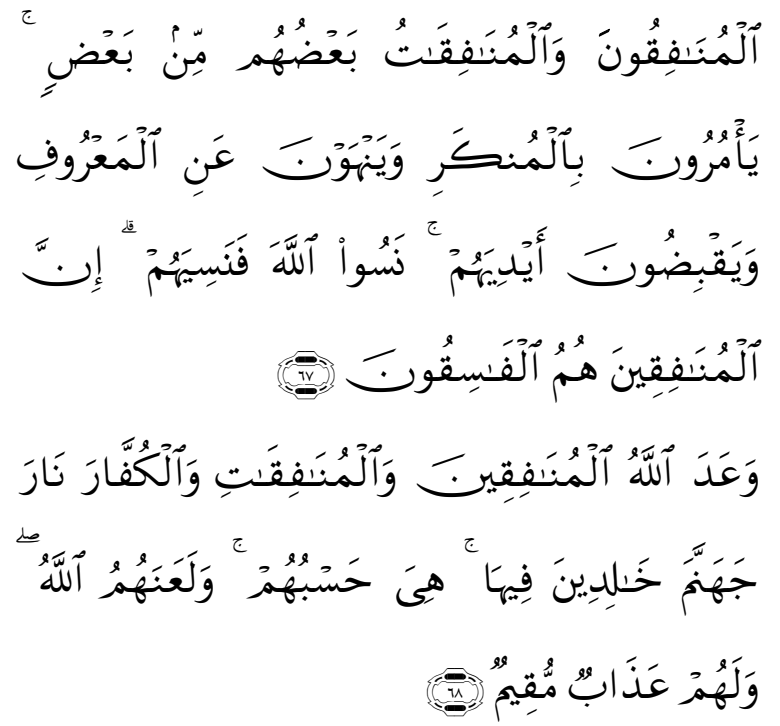

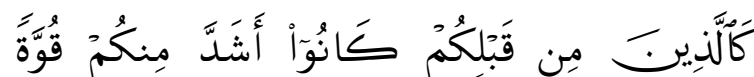

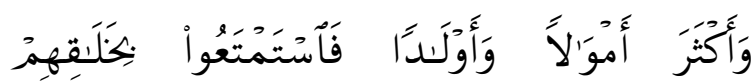

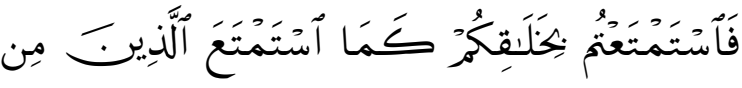

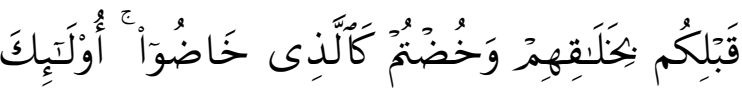
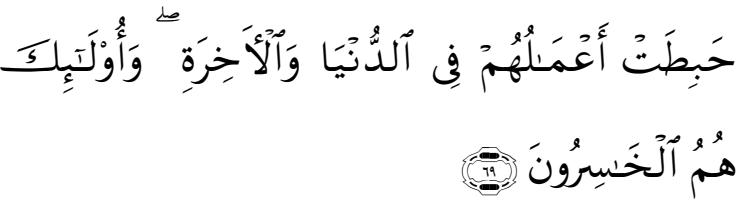

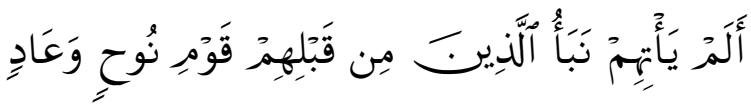

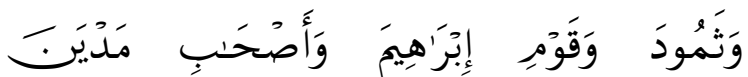

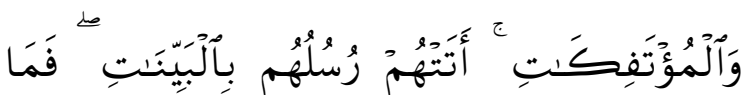

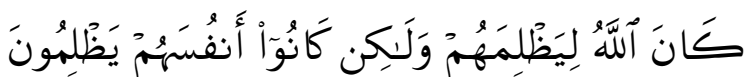

67. Orang-orang munafik laki-laki dan perempuan. sebagian dengan sebagian yang lain adalah sama, mereka menyuruh membuat yang munkar dan melarang berbuat yang ma'ruf dan mereka menggenggamkan tangannya. mereka Telah lupa kepada Allah, Maka Allah melupakan mereka. Sesungguhnya orang-orang munafik itu adalah orang-orang yang fasik.

68. Allah mengancam orang-orang munafik laki-laki dan perempuan dan orang-orang kafir dengan neraka Jahannam, mereka kekal di dalamnya. cukuplah neraka itu bagi mereka, dan Allah mela'nati mereka, dan bagi mereka azab yang kekal.

69. (keadaan kamu Hai orang-orang munafik dan musyrikin) adalah seperti keadaan orang-orang sebelum kamu, mereka lebih Kuat daripada kamu, dan lebih banyak harta dan anak-anaknya dari kamu. Maka mereka Telah menikmati bagian mereka, dan kamu Telah menikmati bagian kamu sebagaimana orang-orang yang sebelummu menikmati bagiannya, dan kamu mempercakapkan (hal yang batil) sebagaimana mereka mempercakapkannya. mereka itu amalannya menjadi sia-sia di dunia dan di akhirat; dan mereka Itulah orang-orang yang merugi.

70. Belumkah datang kepada mereka berita penting tentang orang-orang yang sebelum mereka, (yaitu) kaum Nuh, 'Aad, Tsamud, kaum Ibrahim, 
penduduk Madyan dan negeri-negeri yang Telah musnah?. Telah datang kepada mereka rasul-rasul dengan membawa keterangan yang nyata, Maka Allah tidaklah sekali-kali menganiaya mereka, akan tetapi merekalah yang menganiaya diri mereka sendiri.

Maksudnya: berlaku kikir, Aad adalah kaum nabi Hud, Tsamud ialah kaum nabi Shaleh; penduduk Madyan ialah kaum nabi Syu'aib, dan penduduk negeri yang Telah musnah adalah kaum nabi Luth a.s.

QS. Al Ahzab (33) : 60-62

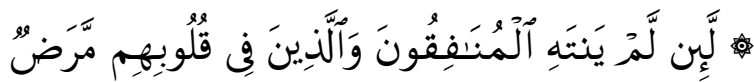

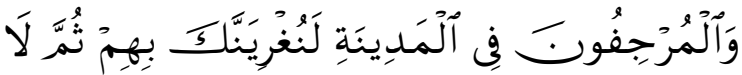

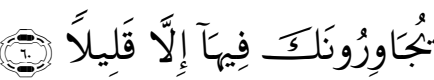

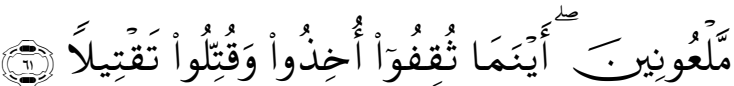

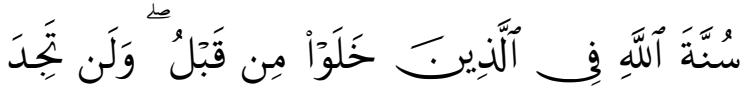

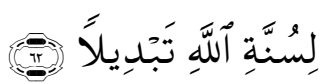

60. Sesungguhnya jika tidak berhenti orang-orang munafik, orang- orang yang berpenyakit dalam hatinya dan orang-orang yang menyebarkan kabar bohong di Madinah (dari menyakitimu), niscaya kami perintahkan kamu (untuk memerangi) mereka, Kemudian mereka tidak menjadi tetanggamu (di Madinah) melainkan dalam waktu yang sebentar,

61. Dalam keadaan terlaknat. di mana saja mereka dijumpai, mereka ditangkap dan dibunuh dengan sehebat-hebatnya.

62. Sebagai sunnah Allah yang berlaku atas orang-orang yang Telah terdahulu sebelum (mu), dan kamu sekali-kali tiada akan mendapati peubahan pada sunnah Allah.
QS. An-Nissa (4) :77-83

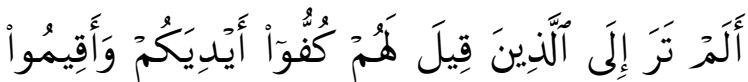

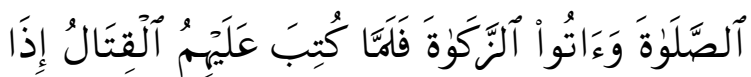

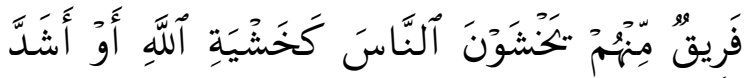

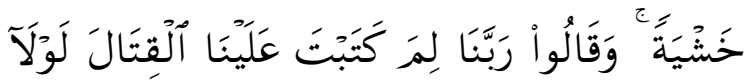

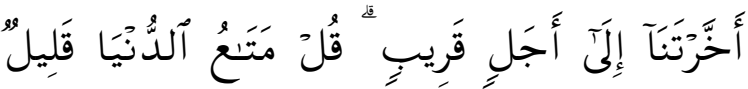

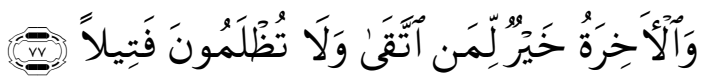

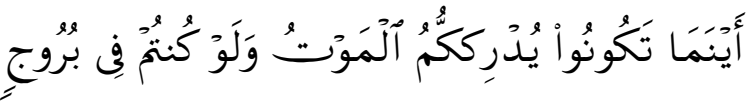

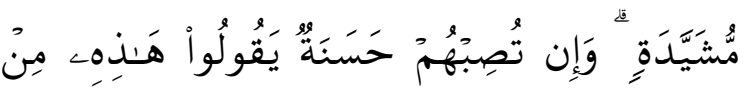

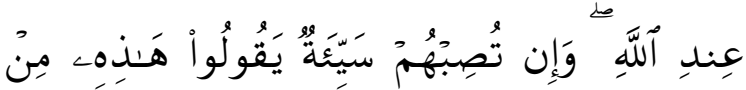

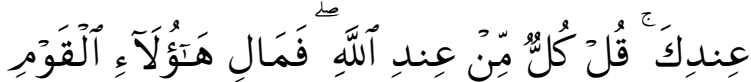

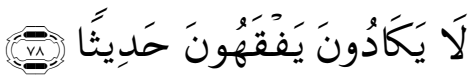

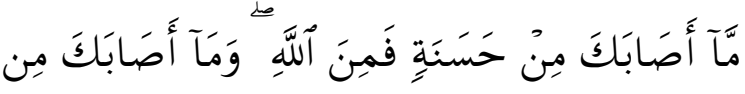

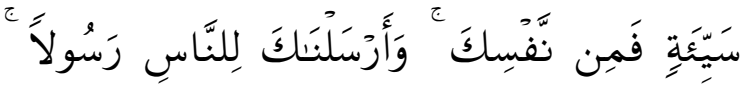
وَكَفَن بِألَّهِ شَهْيدًَا

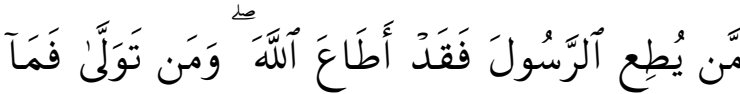

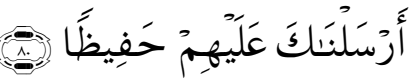

وَيَقُولُوبَ طَاعَةٌ فَإِذَا بَرَزُواْ مِنْ عِندِكَ بَيَّتَ

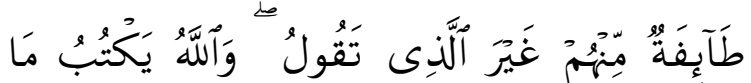

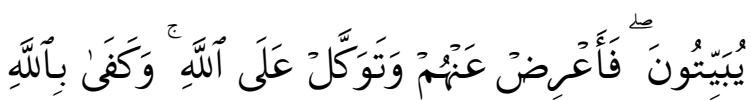
وَكريلاً 


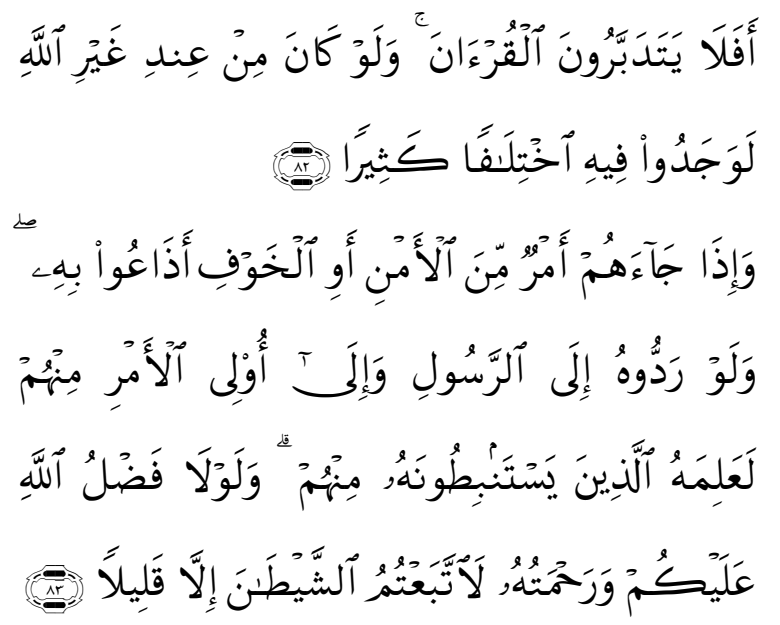

77. Tidakkah kamu perhatikan orangorang yang dikatakan kepada mereka: "Tahanlah tanganmu (dari berperang), Dirikanlah sembahyang dan tunaikanlah zakat!" setelah diwajibkan kepada mereka berperang, tiba-tiba sebahagian dari mereka (golongan munafik) takut kepada manusia (musuh), seperti takutnya kepada Allah, bahkan lebih sangat dari itu takutnya. mereka berkata: "Ya Tuhan kami, Mengapa Engkau wajibkan berperang kepada Kami? Mengapa tidak Engkau tangguhkan (kewajiban berperang) kepada kami sampai kepada beberapa waktu lagi?" Katakanlah: "Kesenangan di dunia Ini Hanya sebentar dan akhirat itu lebih baik untuk orang-orang yang bertakwa, dan kamu tidak akan dianiaya sedikitpun.

78. Di mana saja kamu berada, kematian akan mendapatkan kamu, kendatipun kamu di dalam benteng yang Tinggi lagi kokoh, dan jika mereka memperoleh kebaikan, mereka mengatakan: "Ini adalah dari sisi Allah", dan kalau mereka ditimpa sesuatu bencana mereka mengatakan: "Ini (datangnya) dari sisi kamu (Muhammad)". Katakanlah: "Semuanya (datang) dari sisi Allah". Maka Mengapa orang-orang itu (orang munafik) hampir-hampir tidak memahami pembicaraan sedikitpun?

79. Apa saja nikmat yang kamu peroleh adalah dari Allah, dan apa saja bencana yang menimpamu, Maka dari (kesalahan) dirimu sendiri. kami mengutusmu menjadi Rasul kepada segenap manusia. dan cukuplah Allah menjadi saksi.

80. Barangsiapa yang mentaati Rasul itu, Sesungguhnya ia Telah mentaati Allah. dan barangsiapa yang berpaling (dari ketaatan itu), Maka kami tidak mengutusmu untuk menjadi pemelihara bagi mereka.

81. Dan mereka (orang-orang munafik) mengatakan: "(Kewajiban kami hanyalah) taat". tetapi apabila mereka Telah pergi dari sisimu, sebahagian dari mereka mengatur siasat di malam hari (mengambil keputusan) lain dari yang Telah mereka katakan tadi. Allah menulis siasat yang mereka atur di malam hari itu, Maka berpalinglah kamu dari mereka dan tawakallah kepada Allah. cukuplah Allah menjadi Pelindung.

82. Maka apakah mereka tidak memperhatikan Al Quran? kalau kiranya Al Quran itu bukan dari sisi Allah, tentulah mereka mendapat pertentangan yang banyak di dalamnya.

83. Dan apabila datang kepada mereka suatu berita tentang keamanan ataupun ketakutan, mereka lalu menyiarkannya. dan kalau mereka menyerahkannya kepada Rasul dan ulil Amri di antara mereka, tentulah orangorang yang ingin mengetahui kebenarannya (akan dapat) mengetahuinya dari mereka (rasul dan ulil Amri). kalau tidaklah Karena karunia dan rahmat Allah kepada kamu, tentulah kamu mengikut syaitan, kecuali sebahagian kecil saja (di antaramu). orang-orang yang menampakkan dirinya beriman dan 
minta izin berperang sebelum ada perintah berperang.

artinya pahala turut berperang tidak akan dikurangi sedikitpun. kemenangan dalam peperangan atau rezki. pelajaran dan nasehat-nasehat yang diberikan.Rasul tidak bertanggung jawab terhadap perbuatan-perbuatan mereka dan tidak menjamin agar mereka tidak berbuat kesalahan, ialah: tokoh-tokoh sahabat dan para cendekiawan di antara mereka. menurut Mufassirin yang lain maksudnya ialah: kalau suatu berita tentang keamanan dan ketakutan itu disampaikan kepada Rasul dan ulil Amri, tentulah Rasul dan ulil amri yang ahli dapat menetapkan kesimpulan (istimbat) dari berita itu.

\section{QS. At-Taubah (9) : 81-83}

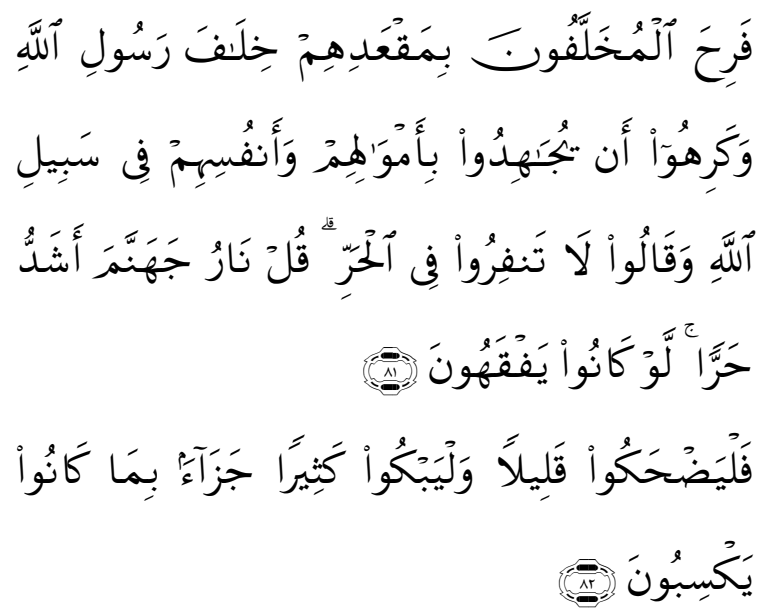

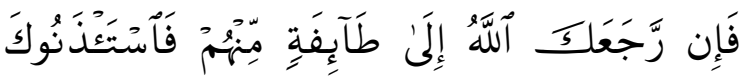

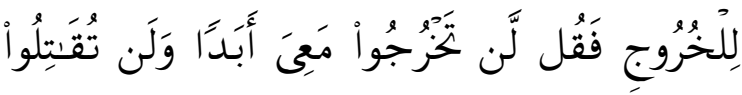

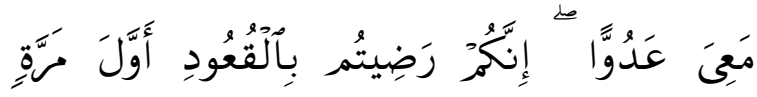

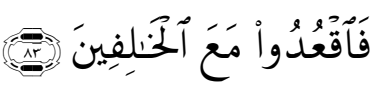

81. Orang-orang yang ditinggalkan (Tidak ikut perang) itu, merasa gembira dengan tinggalnya mereka di belakang
Rasulullah, dan mereka tidak suka berjihad dengan harta dan jiwa mereka pada jalan Allah dan mereka berkata: "Janganlah kamu berangkat (pergi berperang) dalam panas terik ini". Katakanlah: "Api neraka Jahannam itu lebih sangat panas(nya)" jika mereka Mengetahui.

82. Maka hendaklah mereka tertawa sedikit dan menangis banyak, sebagai pembalasan dari apa yang selalu mereka kerjakan.

83. Maka jika Allah mengembalikanmu kepada suatu golongan dari mereka, Kemudian mereka minta izin kepadamu untuk keluar (pergi berperang), Maka Katakanlah: "Kamu tidak boleh keluar bersamaku selama-lamanya dan tidak boleh memerangi musuh bersamaku. Sesungguhnya kamu Telah rela tidak pergi berperang kali yang pertama. Karena itu duduklah bersama orangorang yang tidak ikut berperang. setelah nabi Muhammad saw selesai dari peperangan Tabuk dan kembali ke Madinah dan bertemu segolongan orang-orang munafik yang tidak ikut perang, lalu mereka minta izin kepadanya untuk ikut berperang, Maka nabi Muhammad s.a.w. dilarang oleh Allah untuk mengabulkan permintaan mereka, Karena mereka dari semula tidak mau ikut berperang.

\section{QS. (9) : 86-90}

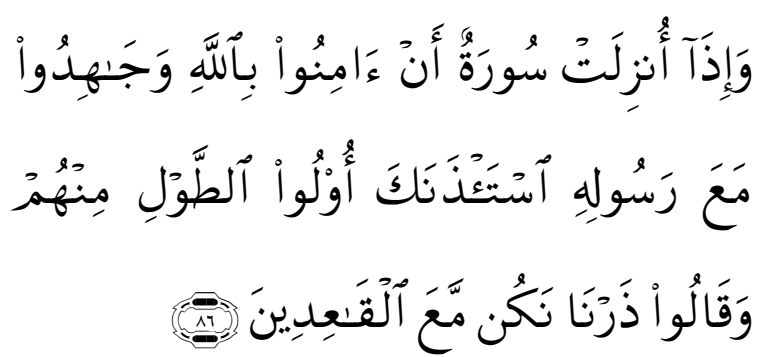



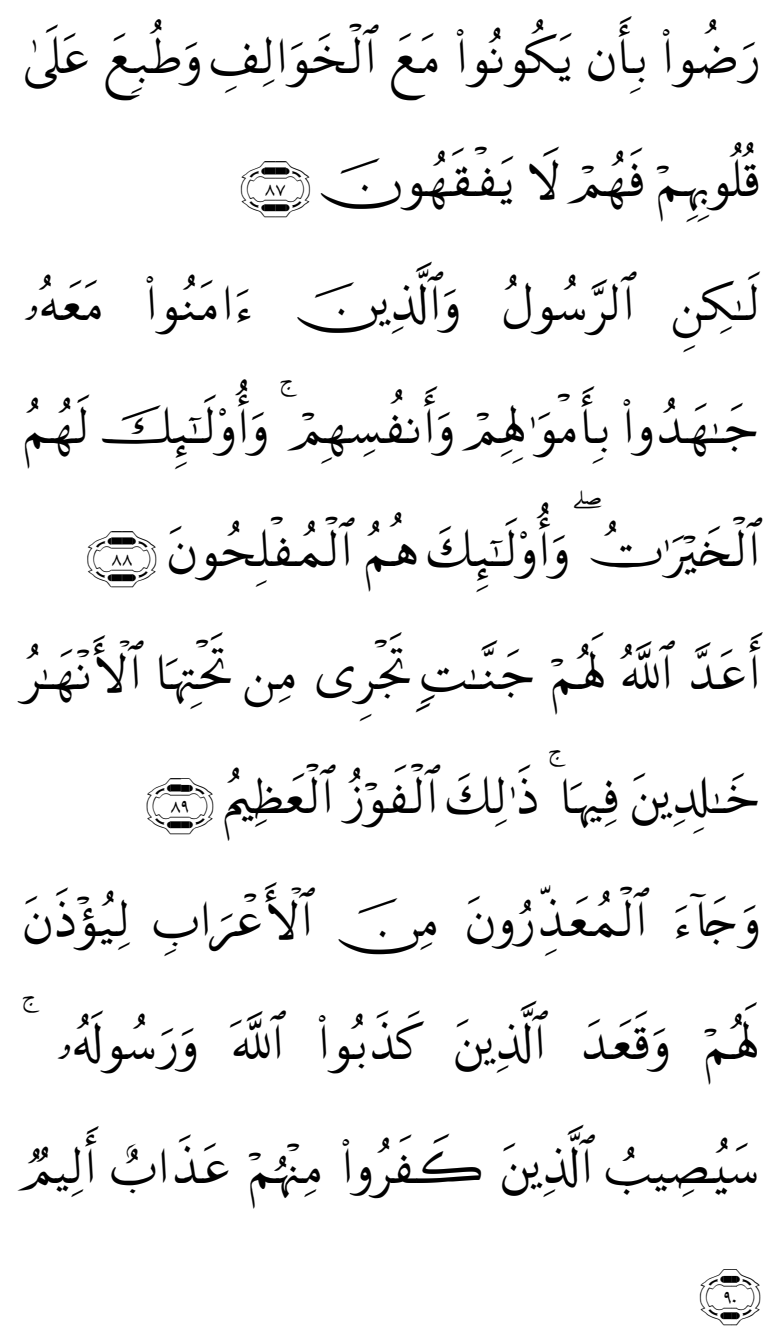

86. Dan apabila diturunkan suatu surat (yang memerintahkan kepada orang munafik itu): "Berimanlah kamu kepada Allah dan berjihadlah beserta Rasul-Nya", niscaya orang-orang yang sanggup di antara mereka meminta izin kepadamu (untuk tidak berjihad) dan mereka berkata: "Biarkanlah kami berada bersama orang-orang yang duduk.

87. Mereka rela berada bersama orangorang yang tidak berperang, dan hati mereka Telah dikunci mati Maka mereka tidak mengetahui (kebahagiaan beriman dan berjihad).

88. Tetapi Rasul dan orang-orang yang beriman bersama Dia, mereka berjihad dengan harta dan diri mereka. dan mereka Itulah orang-orang yang memperoleh kebaikan, dan mereka Itulah orang-orang yang beruntung.

89. Allah Telah menyediakan bagi mereka syurga yang mengalir di bawahnya sungai-sungai, mereka kekal di dalamnya. Itulah kemenangan yang besar.

90. Dan datang (kepada Nabi) orangorang yang mengemukakan 'uzur, yaitu orang-orang Arab Baswi agar diberi izin bagi mereka (untuk tidak berjihad), sedang orang-orang yang mendustakan Allah dan Rasul-Nya, duduk berdiam diri saja. kelak orang-orang yang kafir di antara mereka itu akan ditimpa azab yang pedih.

\section{QS. Al Hasyr (59) :11-17}

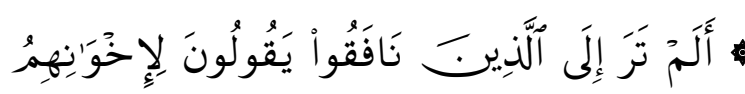

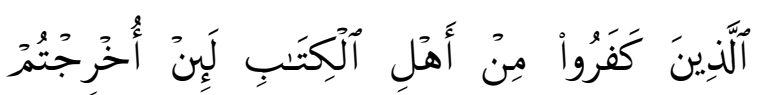

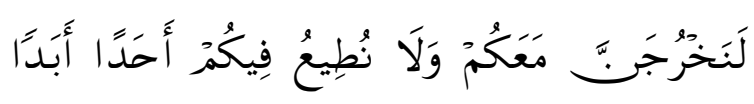

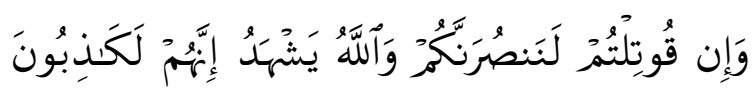

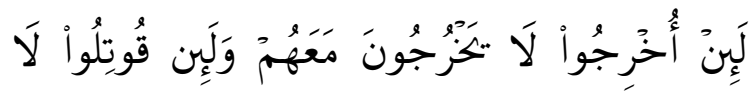

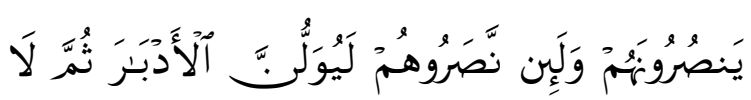
يُنَصَوُبَتَ

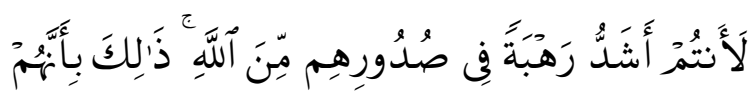
قَوْمُ لاَّ يَفْقَهُوبَ

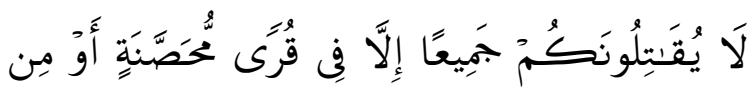

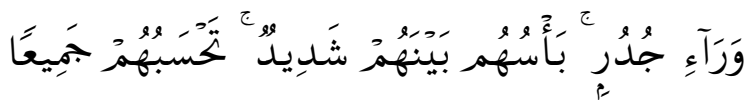

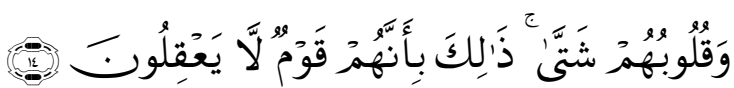




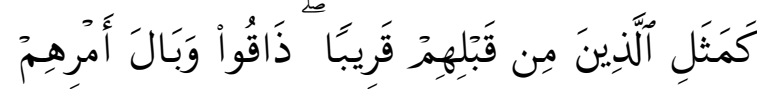

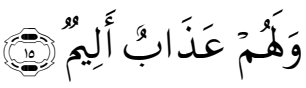

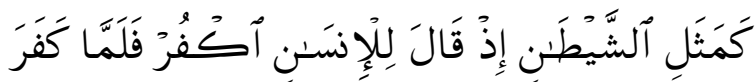

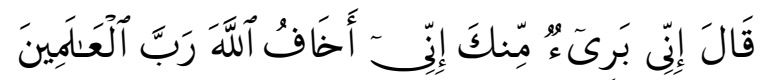

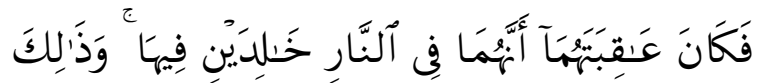

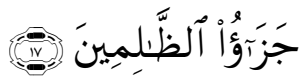

11. Apakah kamu tidak memperhatikan orang-orang munafik yang Berkata kepada Saudara-saudara mereka yang kafir[1467] di antara ahli kitab: "Sesungguhnya jika kamu diusir niscaya kamipun akan keluar bersamamu; dan kami selama-lamanya tidak akan patuh kepada siapapun untuk (menyusahkan) kamu, dan jika kamu diperangi pasti kami akan membantu kamu." dan Allah menyaksikan bahwa Sesungguhnya mereka benar-benar pendusta.

12. Sesungguhnya jika mereka diusir, orang-orang munafik itu tidak akan keluar bersama mereka, dan Sesungguhnya jika mereka diperangi, niscaya mereka tidak akan menolongnya; Sesungguhnya jika mereka menolongnya, niscaya mereka akan berpaling lari ke belakang; Kemudian mereka tidak akan mendapat pertolongan.

13. Sesungguhnya kamu dalam hati mereka lebih ditakuti daripada Allah. yang demikian itu Karena mereka adalah kaum yang tidak mengerti.

14. Mereka tidak akan memerangi kamu dalam keadaan bersatu padu, kecuali dalam kampung-kampung yang berbenteng atau di balik tembok. permusuhan antara sesama mereka adalah sangat hebat. kamu kira mereka itu bersatu, sedang hati mereka berpecah belah. yang demikian itu Karena Sesungguhnya mereka adalah kaum yang tidak mengerti.

15. (mereka adalah) seperti orang-orang Yahudi yang belum lama sebelum mereka[1468] Telah merasai akibat buruk dari perbuatan mereka[1469], dan bagi mereka azab yang pedih.

16. (Bujukan orang-orang munafik itu adalah) seperti (bujukan) shaitan ketika dia Berkata kepada manusia: "Kafirlah kamu", Maka tatkala manusia itu Telah kafir, Maka ia berkata: "Sesungguhnya Aku berlepas diri dari kamu, Karena Sesungguhnya Aku takut kepada Allah, Rabb semesta alam".

17. Maka adalah kesudahan keduanya, bahwa Sesungguhnya keduanya (masuk) ke dalam neraka, mereka kekal di dalamnya. Demikianlah balasan orang-orang yang zalim.

QS. At-Taubah (9) : 73-74
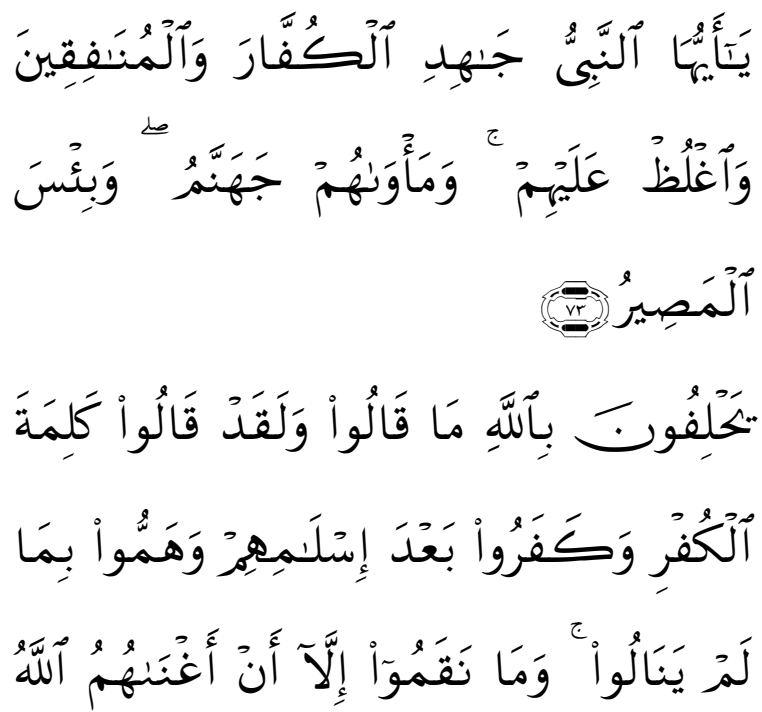

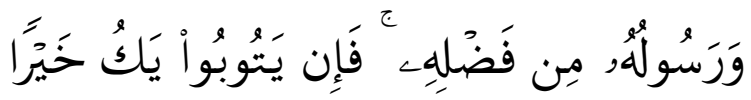

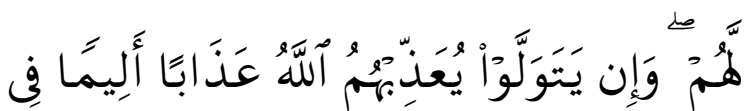




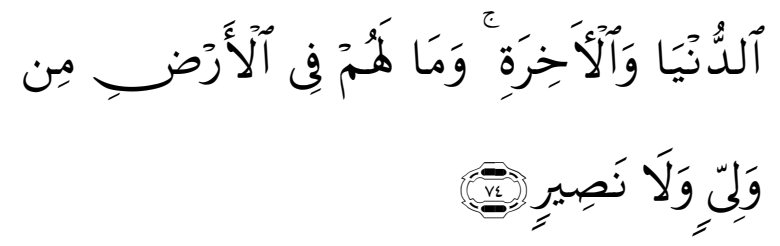

73. Hai nabi, berjihadlah (melawan) orang-orang kafir dan orang-orang munafik itu, dan bersikap keraslah terhadap mereka. tempat mereka ialah jahannam. dan itu adalah tempat kembali yang seburuk-buruknya.

74. Mereka (orang-orang munafik itu) bersumpah dengan (nama) Allah, bahwa mereka tidak mengatakan (sesuatu yang menyakitimu). Sesungguhnya mereka Telah mengucapkan perkataan kekafiran, dan Telah menjadi kafir sesudah Islam dan mengingini apa yang mereka tidak dapat mencapainya[650], dan mereka tidak mencela (Allah dan Rasul-Nya), kecuali Karena Allah dan rasul-Nya Telah melimpahkan karunia-Nya kepada mereka. Maka jika mereka bertaubat, itu adalah lebih baik bagi mereka, dan jika mereka berpaling, niscaya Allah akan mengazab mereka dengan azab yang pedih di dunia dan akhirat; dan mereka sekali-kali tidaklah mempunyai pelindung dan tidak (pula) penolong di muka bumi.

QS. (9) : 75-78
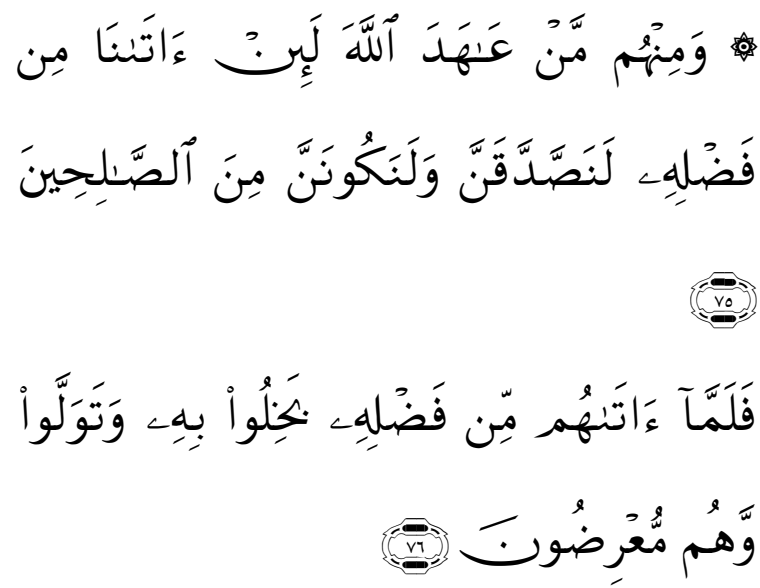

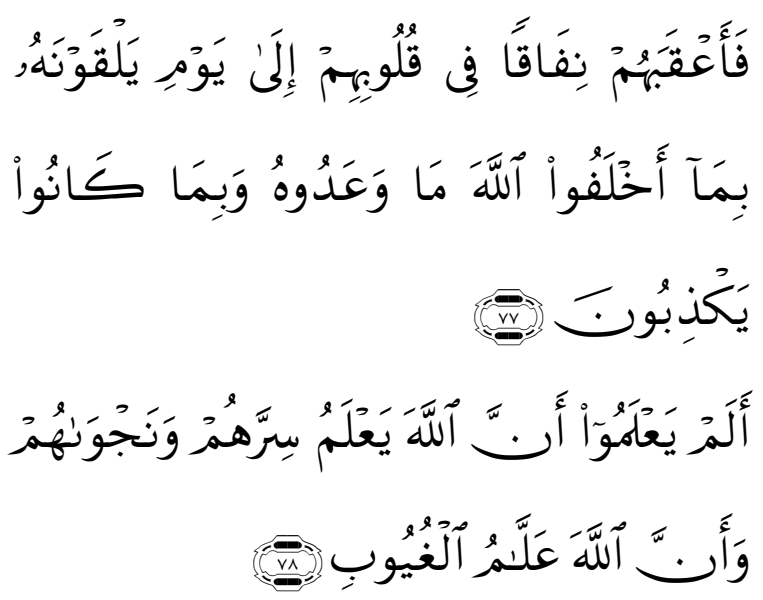

75. Dan diantara mereka ada orang yang Telah berikrar kepada Allah: "Sesungguhnya jika Allah memberikan sebahagian karunia-Nya kepada kami, Pastilah kami akan bersedekah dan Pastilah kami termasuk orang-orang yang saleh.

76. Maka setelah Allah memberikan kepada mereka sebahagian dari karunia-Nya, mereka kikir dengan karunia itu, dan berpaling, dan mereka memanglah orang-orang yang selalu membelakangi (kebenaran).

77. Maka Allah menimbulkan kemunafikan pada hati mereka sampai kepada waktu mereka menemui Allah, Karena mereka Telah memungkiri terhadap Allah apa yang Telah mereka ikrarkan kepadaNya dan juga Karena mereka selalu berdusta.

78. Tidaklah mereka tahu bahwasanya Allah mengetahui rahasia dan bisikan mereka, dan bahwasanya Allah amat mengetahui segala yang ghaib.

QS. (9) : 79-80

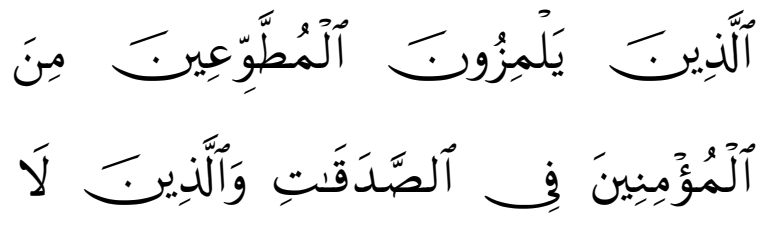




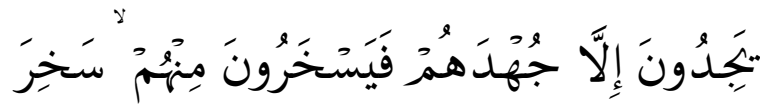

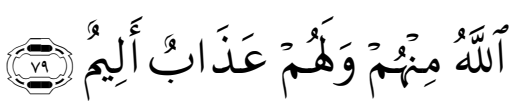

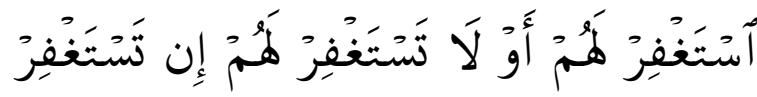

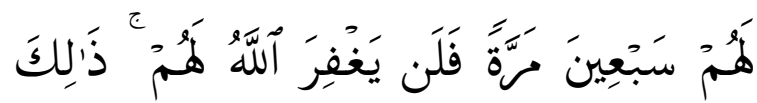

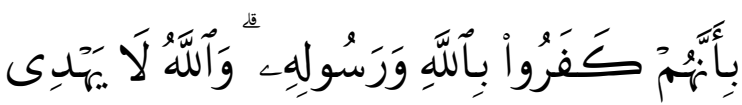

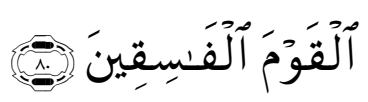

79. (orang-orang munafik itu) yaitu orangorang yang mencela orang-orang mukmin yang memberi sedekah dengan sukarela dan (mencela) orang-orang yang tidak memperoleh (untuk disedekahkan) selain sekedar kesanggupannya, Maka orang-orang munafik itu menghina mereka. Allah akan membalas penghinaan mereka itu, dan untuk mereka azab yang pedih.

80. Kamu memohonkan ampun bagi mereka atau tidak kamu mohonkan ampun bagi mereka (adalah sama saja). kendatipun kamu memohonkan ampun bagi mereka tujuh puluh kali, namun Allah sekali-kali tidak akan memberi ampunan kepada mereka. yang demikian itu adalah Karena mereka kafir kepada Allah dan RasulNya. dan Allah tidak memberi petunjuk kepada kaum yang fasik.

QS. (9) : 84-85

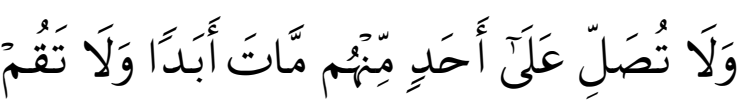

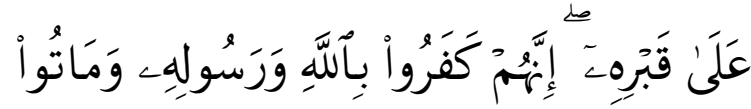

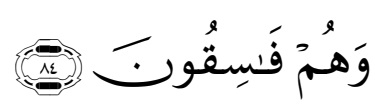

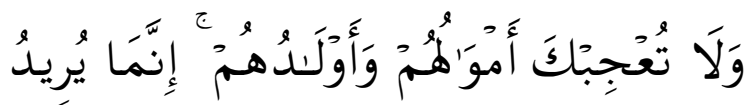

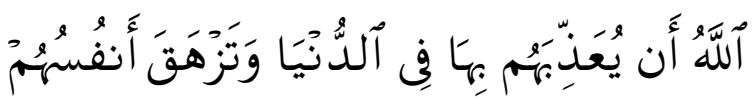

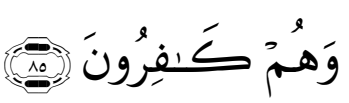

84. Dan janganlah kamu sekali-kali menyembahyangkan (jenazah) seorang yang mati di antara mereka, dan janganlah kamu berdiri (mendoakan) di kuburnya. Sesungguhnya mereka Telah kafir kepada Allah dan rasulNya dan mereka mati dalam keadaan fasik.

85. Dan janganlah harta benda dan anakanak mereka menarik hatimu. Sesungguhnya Allah menghendaki akan mengazab mereka di dunia dengan harta dan anak-anak itu dan agar melayang nyawa mereka, dalam keadaan kafir.

QS. An-Nuur (24) : 47-50

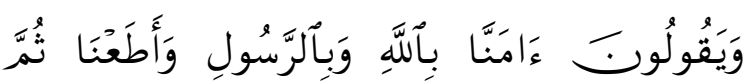

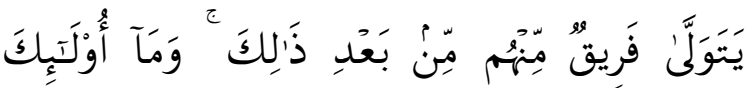

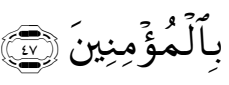

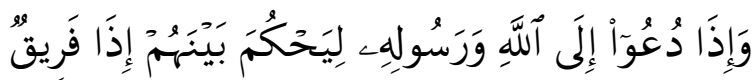

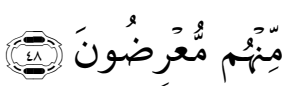

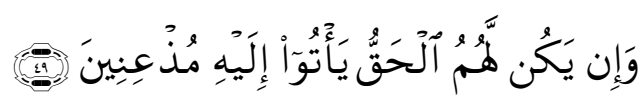

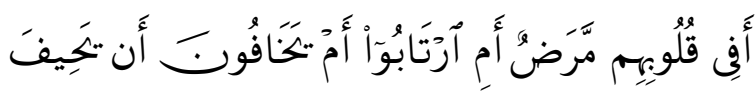

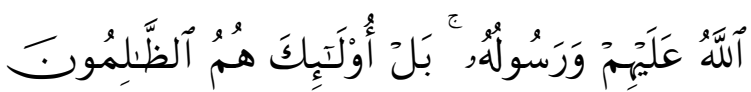

47. Dan mereka berkata: "Kami Telah beriman kepada Allah dan rasul, dan kami mentaati (keduanya)." Kemudian 
sebagian dari mereka berpaling sesudah itu, sekali-kali mereka itu bukanlah orang-orang yang beriman.

48. Dan apabila mereka dipanggil kepada Allah[1044] dan Rasul-Nya, agar Rasul menghukum (mengadili) di antara mereka, tiba-tiba sebagian dari mereka menolak untuk datang.

49. Tetapi jika Keputusan itu untuk (kemaslahatan) mereka, mereka datang kepada Rasul dengan patuh.

50. Apakah (ketidak datangan mereka itu karena) dalam hati mereka ada penyakit, atau (karena) mereka raguragu ataukah (karena) takut kalaukalau Allah dan rasul-Nya berlaku zalim kepada mereka? Sebenarnya, mereka Itulah orang-orang yang zalim.

Maksudnya: dipanggil utnuk bertahkim kepada Kitabullah.

\section{QS. Huud (11) :}
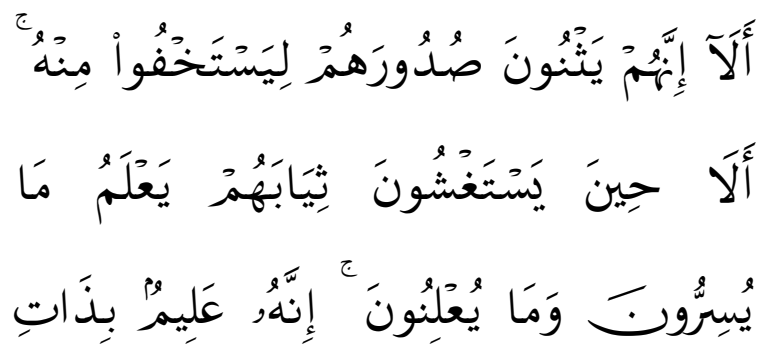

$$
\text { آلصَّدُورِ }
$$

5. Ingatlah, Sesungguhnya (orang munafik itu) memalingkan dada mereka untuk menyembunyikan diri daripadanya (Muhammad)[708]. Ingatlah, di waktu mereka menyelimuti dirinya dengan kain, Allah mengetahui apa yang mereka sembunyikan dan apa yang mereka lahirkan, Sesungguhnya Allah Maha mengetahui segala isi hati.

Maksudnya: menyembunyikan perasaan permusuhan dan kemunafikan mereka terhadap nabi Muhammad s.a.w.
QS. Al-Baqarah (2) : 204-206

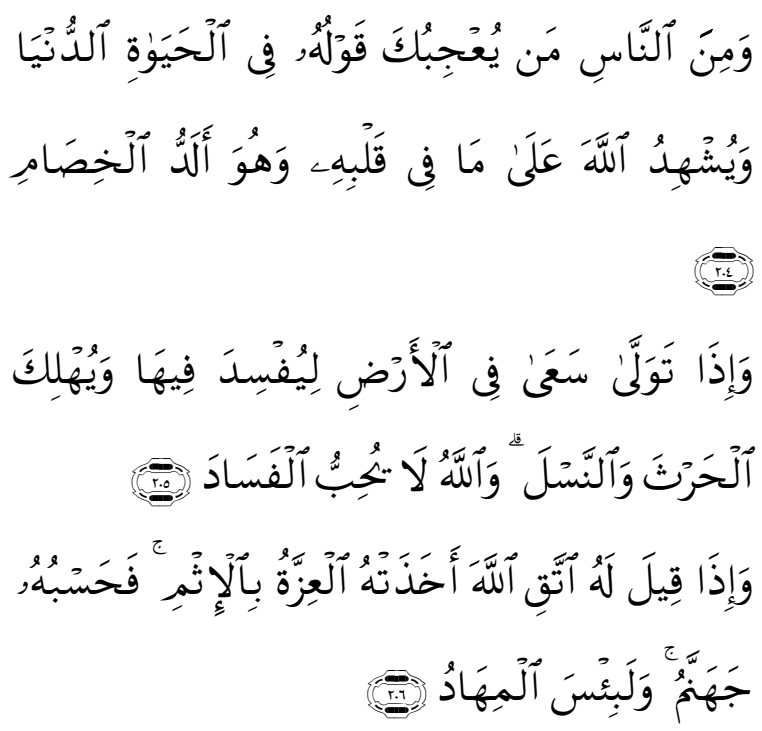

204. Dan di antara manusia ada orang yang ucapannya tentang kehidupan dunia menarik hatimu, dan dipersaksikannya kepada Allah (atas kebenaran) isi hatinya, padahal ia adalah penantang yang paling keras.

205. Dan apabila ia berpaling (dari kamu), ia berjalan di bumi untuk mengadakan kerusakan padanya, dan merusak tanam-tanaman dan binatang ternak, dan Allah tidak menyukai kebinasaan[130].

206. Dan apabila dikatakan kepadanya: "Bertakwalah kepada Allah", bangkitlah kesombongannya yang menyebabkannya berbuat dosa. Maka cukuplah (balasannya) neraka jahannam. dan sungguh neraka Jahannam itu tempat tinggal yang seburuk-buruknya. [130] Ungkapan Ini adalah ibarat dari orang-orang yang berusaha menggoncangkan iman orang-orang mukmin dan selalu mengadakan pengacauan. 


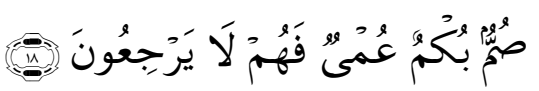

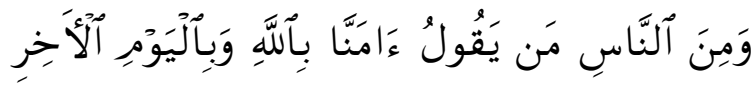

$$
\text { وَمَا هُم بِمُؤْمِنِينَ }
$$

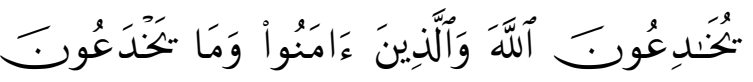

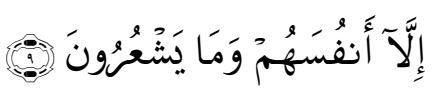

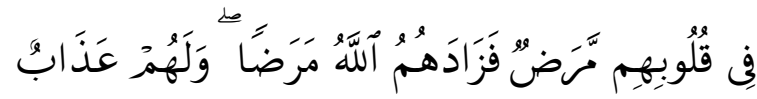

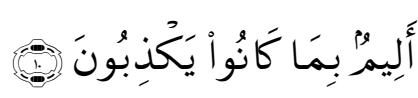

وَإِذَا قِيَلَ لَهُمْ لَا تُفسِدُواً فِى ألَأَرْضِ قَالُوَاْ إِنَّمَا

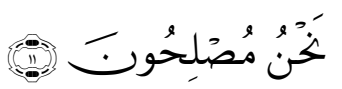

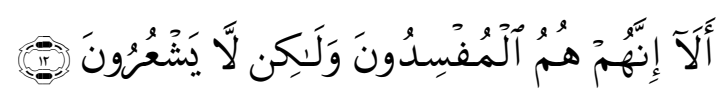

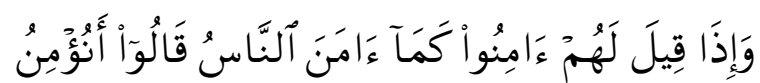

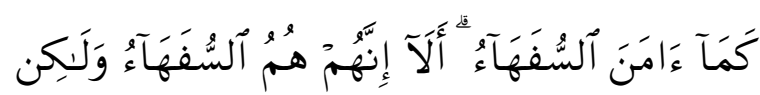

$$
\text { لَّ يَحِلَمَونَ }
$$

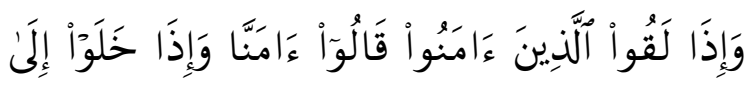

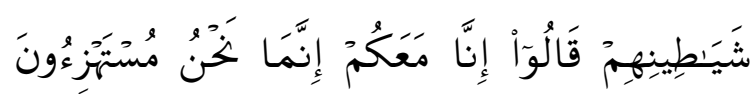

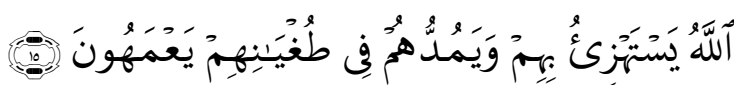

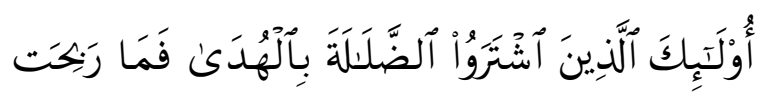

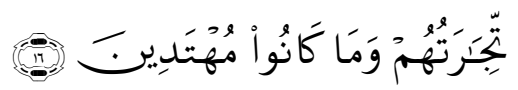

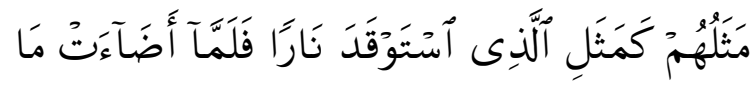

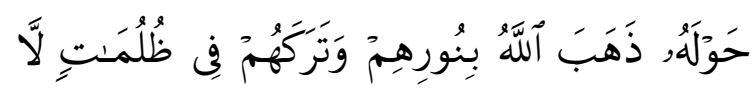
يُبْصِرونَ

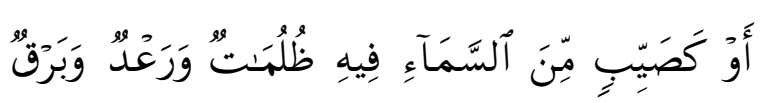

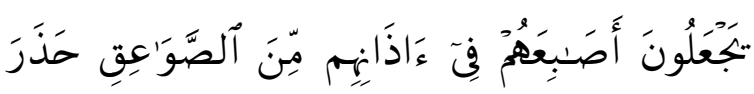

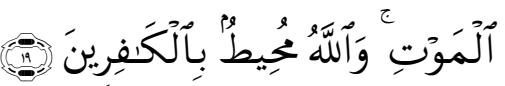

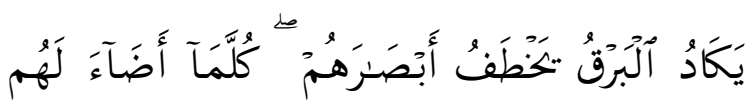

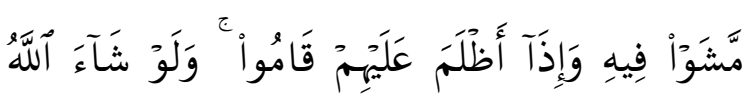

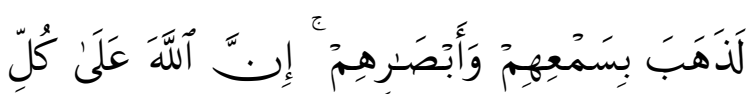
شَنْ قَدِيرِ

8. Di antara manusia ada yang mengatakan: "Kami beriman kepada Allah dan hari kemudian[22]," pada hal mereka itu Sesungguhnya bukan orang-orang yang beriman.

9. Mereka hendak menipu Allah dan orang-orang yang beriman, padahal mereka Hanya menipu dirinya sendiri sedang mereka tidak sadar.

10. Dalam hati mereka ada penyakit[23], lalu ditambah Allah penyakitnya; dan bagi mereka siksa yang pedih, disebabkan mereka berdusta.

11. Dan bila dikatakan kepada mereka:"Janganlah kamu membuat kerusakan di muka bumi[24]". mereka menjawab: "Sesungguhnya kami orang-orang yang mengadakan perbaikan."

12. Ingatlah, Sesungguhnya mereka Itulah orang-orang yang membuat kerusakan, tetapi mereka tidak sadar.

13. Apabila dikatakan kepada mereka: "Berimanlah kamu sebagaimana orang-orang lain Telah beriman." mereka menjawab: "Akan berimankah kami sebagaimana orang-orang yang bodoh itu Telah beriman?" Ingatlah, Sesungguhnya merekalah orang-orang yang bodoh; tetapi mereka tidak tahu. 
14. Dan bila mereka berjumpa dengan orang-orang yang beriman, mereka mengatakan: "Kami Telah beriman". dan bila mereka kembali kepada syaitan-syaitan mereka[25], mereka mengatakan: "Sesungguhnya kami sependirian dengan kamu, kami hanyalah berolok-olok."

15. Allah akan (membalas) olok-olokan mereka dan membiarkan mereka terombang-ambing dalam kesesatan mereka.

16. Mereka Itulah orang yang membeli kesesatan dengan petunjuk, Maka tidaklah beruntung perniagaan mereka dan tidaklah mereka mendapat petunjuk.

17. Perumpamaan mereka adalah seperti orang yang menyalakan api[26], Maka setelah api itu menerangi sekelilingnya Allah hilangkan cahaya (yang menyinari) mereka, dan membiarkan mereka dalam kegelapan, tidak dapat Melihat.

18. Mereka tuli, bisu dan buta[27], Maka tidaklah mereka akan kembali (ke jalan yang benar),

19. Atau seperti (orang-orang yang ditimpa) hujan lebat dari langit disertai gelap gulita, guruh dan kilat; mereka menyumbat telinganya dengan anak jarinya, Karena (mendengar suara) petir,sebab takut akan mati[28]. dan Allah meliputi orang-orang yang kafir [29].

20. Hampir-hampir kilat itu menyambar penglihatan mereka. setiap kali kilat itu menyinari mereka, mereka berjalan di bawah sinar itu, dan bila gelap menimpa mereka, mereka berhenti. Jikalau Allah menghendaki, niscaya dia melenyapkan pendengaran dan penglihatan mereka. Sesungguhnya Allah berkuasa atas segala sesuatu. [22] Hari kemudian ialah: mulai dari waktu mahluk dikumpulkan di padang mahsyar sampai waktu yang tak ada batasnya. [23] yakni keyakinan mereka terdahap kebenaran nabi Muhammad s.a.w. lemah. Kelemahan keyakinan itu, menimbulkan kedengkian, iri-hati dan dendam terhadap nabi s.a.w., agama dan orang-orang Islam. [24] kerusakan yang mereka perbuat di muka bumi bukan berarti kerusakan benda, melainkan menghasut orang-orang kafir untuk memusuhi dan menentang orang-orang Islam. [25] Maksudnya: pemimpin-pemimpin mereka. [26] orang-orang munafik itu tidak dapat mengambil manfaat dari petunjukpetunjuk yang datang dari Allah, Karena sifat-sifat kemunafikkan yang bersemi dalam dada mereka. keadaan mereka digambarkan Allah seperti dalam ayat tersebut di atas. [27] walaupun pancaindera mereka sehat mereka dipandang tuli, bisu dan buta oleh Karena tidak dapat menerima kebenaran. [28] keadaan orang-orang munafik itu, ketika mendengar ayatayat yang mengandung peringatan, adalah seperti orang yang ditimpa hujan lebat dan petir. mereka menyumbat telinganya Karena tidak sanggup mendengar peringatanperingatan Al Quran itu. [29] maksudnya pengetahuan dan kekuasaan Allah meliputi orang-orang kafir.

QS. At-Taubah (9) : 58-59

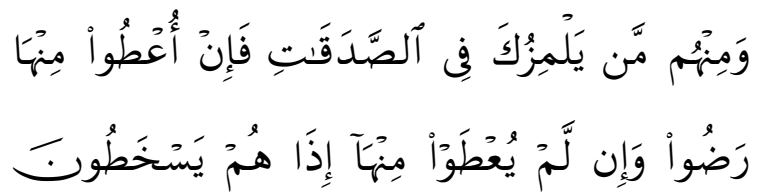




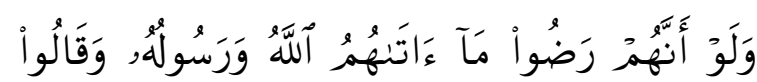

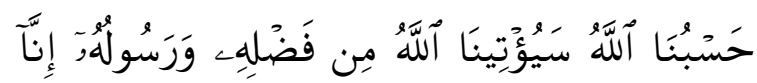

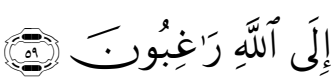

58. Dan di antara mereka ada orang yang mencelamu tentang (distribusi) zakat; jika mereka diberi sebahagian dari padanya, mereka bersenang hati, dan jika mereka tidak diberi sebahagian dari padanya, dengan serta merta mereka menjadi marah.

59. Jikalau mereka sungguh-sungguh ridha dengan apa yang diberikan Allah dan RasulNya kepada mereka, dan berkata: "Cukuplah Allah bagi kami, Allah akan memberikan sebagian dari karuniaNya dan demikian (pula) Rasul-Nya, Sesungguhnya kami adalah orangorang yang berharap kepada Allah," (tentulah yang demikian itu lebih baik bagi mereka).

\section{ANALISIS TERHADAP AYAT}

\begin{tabular}{|c|c|c|c|}
\hline No & T E M A & Surat & Ayat \\
\hline 1 & $\begin{array}{l}\text { Sifat-sifat orang } \\
\text { munafik }\end{array}$ & $\begin{array}{l}\text { QS. Ali Imran (3) } \\
\text { QS. Al Munaafiqun } \\
\text { (63) }\end{array}$ & $\begin{array}{l}165-168 \\
1-8\end{array}$ \\
\hline 2 & $\begin{array}{l}\text { Cara menghadapi } \\
\text { orang munafik }\end{array}$ & QS. An Nissa (4) & $88-91$ \\
\hline 3 & $\begin{array}{l}\text { Hasutan orang- } \\
\text { orang munafik dan } \\
\text { ancaman Allah } \\
\text { kepada mereka }\end{array}$ & $\begin{array}{l}\text { QS. At Taubah (9) } \\
\text { QS. Al Ahzab (33) }\end{array}$ & $\begin{array}{l}67-70 \\
60-62\end{array}$ \\
\hline 4 & $\begin{array}{l}\text { Sikap orang } \\
\text { munafik dalam } \\
\text { menghadapi } \\
\text { peperangan }\end{array}$ & $\begin{array}{l}\text { QS. An Nissa (4) } \\
\text { QS. At Taubah (9) } \\
\text { QS. At Taubah (9) }\end{array}$ & $\begin{array}{l}77-83 \\
42-43 \\
44-45 \\
81-83 \\
86-90\end{array}$ \\
\hline 5 & $\begin{array}{l}\text { Orang-orang } \\
\text { munafik tidak } \\
\text { menepati janji } \\
\text { kepada orang- } \\
\text { orang yahudi }\end{array}$ & QS. Al Hasyr (59) & $11-17$ \\
\hline 6 & $\begin{array}{l}\text { Keharusan } \\
\text { bersikap tegas } \\
\text { kepada orang- } \\
\text { orang kafir dan } \\
\text { munafik }\end{array}$ & QS. At Taubah (9) & $73-74$ \\
\hline 7 & $\begin{array}{l}\text { Ikrar orang-orang } \\
\text { munafik tak dapat }\end{array}$ & QS. At Taubah (9) & $75-78$ \\
\hline
\end{tabular}

\begin{tabular}{|c|l|l|l|}
\hline & dipercaya & & \\
\hline 8 & $\begin{array}{l}\text { Kemunafikkan } \\
\text { adalah dosa yang } \\
\text { tidak diampuni } \\
\text { Allah }\end{array}$ & QS. At Taubah (9) & $79-80$ \\
\hline 9 & $\begin{array}{l}\text { Larangan } \\
\text { menyembahyangi } \\
\text { jenazah orang } \\
\text { munafik }\end{array}$ & QS. At Taubah (9) & $84-85$ \\
\hline 10 & $\begin{array}{l}\text { Perbedaan sikap } \\
\text { orang-orang } \\
\text { munafik dan orang- } \\
\text { orang yang } \\
\text { mukmin dalam } \\
\text { bertahkim kepada } \\
\text { rasul }\end{array}$ & $\begin{array}{l}\text { QS. An Nuur (24) } \\
\text { QS. Huud (11) }\end{array}$ & $57-50$ \\
\hline 11 & $\begin{array}{l}\text { Perbuatan orang- } \\
\text { orang munafik }\end{array}$ & QS. Al Baqarah (2) & 204-206 \\
\hline 12 & Golongan munafik & QS. Al Baqarah (2) & $8-20$ \\
\hline 13 & $\begin{array}{l}\text { Sikap orang } \\
\text { munafik dalam } \\
\text { pembagian sedekah }\end{array}$ & QS. At Taubah (9) & $58-59$ \\
\hline
\end{tabular}

\section{KESIMPULAN}

Tanda orang munafik ada tiga :

- Apabila ia berbicara berdusta,

- Apabila ia berjani ia ingkar, dan

- Apabila dia dipercayai ia berkhianat.

Menurut ( An-Najati ) ciri-ciri yang dikemukakan Al-Quran adalah :

- Sifat-sifat yang berkaitan dengan akidah : tak mempunyai sikap yang jelas berkenaan dengan keyakinan tauhid. Mereka menunjukkan keimanan bila bertemu dengan kaum mukminin serta memperlihatkan kemusyrikan bila bertemu dengan orang-orang musyrik. (QS. 3:156,167), (QS. 9:81), (QS. 59:11),(QS. 4:65), (QS. 2:14-15).

- Sifat-sifat yang berkaitan dengan peribadatan : menjalankan peribadahan karena ria dan tanpa pendirian. Apabila menunaikan shalat, mereka suka bermalas-malasan. (QS. 4:142), (QS. 9:53-54).

- Sifat-sifat yang berkaitan dengan hubungan sosial : selalu menyuruh kemunkaran dan melarang perbuatan baik, berupaya menimbulkan chaos di barisan, dan untuk itu mereka kerap kali menebarkan rumor ; banyak bersumpah untuk membuat orang lain mempercayai mereka; berpenampilan baik untuk 
menarik perhatian dan mempengaruhi orang lain. (QS. 33:60).

- Sifat-sifat yang berkenaan dengan akhlak : kurang percaya diri, suka ingkar janji, ria, pengecut, pendusta, pelit, opurtunis, memperturutkan hawa nafsu. (QS. 9:75-77), (QS. 63:1), (QS. 9:74), (QS. 9:56), (QS. 47:16), (QS. 25:43).

- Sifat-sifat emosi dan perasaan : penakut, sehingga mereka takut, baik kepada kaum mukminin maupun kepada orangorang musyrik; pengecut dan takut mati, sebab itu mereka tidak turut serta bersama kaum muslimin dalam pepernagan; mereka juga tidak senang dan iri kepada kaum muslimin. (QS. 48:16), (QS. 9:81).

- Sifat-sifat yang berkaitan dengan pemikiran, intelektual atau kognitif : ragu-ragu, bimbang, dan tal mampu membuat keputusan ; tidak mampu berpikir jernih. Oleh karena itu, AlQuran menggambarkan bahwa hati mereka terkunci; cenderung membela diri dengan menjustifikasi tindakantindakan mereka. (QS. 2:10), (QS. 22:11), (QS. 57:13-14).

\section{SARAN}

Munafik adalah golongan orang yang berkepribadian lemah dan bimbang. Mereka tidak dapat membuat suatu sikap yang kelas berkenaan dengan keimanan. Pada dasarnya kaum munafik adalah sekelompom orang penderita penyakit mental yang parah, dan pada umumnya mereka adalah orang-orang yang berjiwa lemah, tidak mempunyai pendirian, seta tidak berprinsip. Dalam bersikap dan menentukan pilihan mereka cenderung ikut arus. Ciri yang paling mendasar adalah kebimbangannya antara keimanan dan kekafiran serta ketakmampuannya membuat sikap yang tegas dan jelas berkaitan dengan keyakinan tauhid. Hal itu karena ia adalah pribadi yang kurang percaya diri. Mereka tidak dapat membuat kepurusan yang tegas dan jelas untuk bergabung dengan kaum mukminin atau dengan kaum musyrikin.

Sikap semacam itu telah menjadikan orang munafik mengambil jalan kebohongan, ria melakukan tipu muslihat, serta menyembunyikan perasaan mereka sesungguhnya, yaitu kebencian, iri hati, dengki.

Dalam menghadapi hal tersebut sangatlah penting ketika seseorang dalam menjalani kehidupannya mengetahui setiap tujuan dari apa yang akan menjadi pilihan hidupnya,memiliki tujuan dalam melakukan apapun yang menjadi kewajibannya. Ketika orang mengetahui tujuan dalam kehidupannya maka kekuatan dari keinginan diri untuk mewujudkan tujuannya tersebut dapat menjadikan seseorang itu memiliki kepribadian yang kuat dan tidak akan berpura-pura.Memiliki rasa takut bahwa segala apapun yang difikirkan,diperbuat setiap manusia di bumi ini akan diminta pertanggunganjawaban kepada Tuhan.Kebaikan dalam berfikir dan berperilaku terhadap sesama umat manusia akan mendatangkan berkah pemilik langit dan ditandai dengan kemudahan dalam menjalani kehidupannya.

\section{Alhamdullilahirrabilalamin}

\section{DAFTAR PUSTAKA}

Abdurrahman, A,A. 2006, 50 Tanda Orang Munafik. Jakarta : Cendikia

Haikal, Ahmad, Ma. 2004, Bahaya Sifat Munafik, Jakrta : Al-Mawardi Prima

Mutjaba, Sayyid. 1990, Psikologi Islam. Bandung : Pustaka Hidayah.

Najati, U, M. 2005, Psikologi Dalam AlQuran, Bandung : Pustaka Setia

Wahbah, Prof, Dr, Ensiklopedia Al-Quran. Jakarta : Gema Insani

Tafsir Al-Quran Online 